\title{
PENGARUH PENUTUPAN MANGROVE TERHADAP PERUBAHAN GARIS PANTAI DAN INTRUSI AIR LAUT DI HILIR DAS CIASEM DAN DAS CIPUNEGARA, KABUPATEN SUBANG \\ (Effect of Mangrove Vegetation Cover to the Shoreline Change and Seawater Intrusion at Downstream of Ciasem and Cipunegara Watershed, Subang District)
}

\author{
Andi Gustiani Salim*, Harris Herman Siringoringo' dan Budi Hadi Narendra \\ Pusat Penelitian dan Pengembangan Hutan, \\ Jl. Gunung Batu no.5 Po Box 165, Bogor, 16118.
}

*Penulis korespondensi. Tel: +628124232732. Email: a_gustiani@yahoo.com.

Diterima: 14 Maret 2016

Disetujui: 1 September 2016

\begin{abstract}
Abstrak
Perubahan penggunaan lahan dari hutan ke penggunaan lainnya seringkali diikuti oleh penurunan fungsi tanah sebagai pengatur tata air. Penelitian ini bertujuan untuk mempelajari pengaruh tutupan mangrove terhadap perubahan garis pantai dan intrusi air laut pada hilir DAS. Penelitian difokuskan pada penentuan jenis penggunaan lahan pantai melalui interpretasi citra satelit dan pengecekan lapangan, analisis kondisi fisik tanah, pengamatan intrusi air laut, dan analisis perubahan garis pantai akibat abrasi atau ekresi. Hasil penelitian menunjukkan pada periode tahun 1989 hingga 2013, tambak yang ditanami mangrove di Kabupaten Subang mengalami penurunan luas dari 3402,6 ha menjadi 2384,9 ha, sebaliknya terjadi peningkatan luas tambak tanpa mangrove dari 5745 ha menjadi 8741,5 ha. Analisis perubahan garis pantai menunjukkan adanya abrasi di Ujung Pamanukan dan Teluk Ciasem mencapai 1,2 km ke arah daratan. Akresi dijumpai di Teluk Blanakan dan Muara Cipunagara mencapai 1,3 km dalam kurun waktu 1989 - 2013, sedangkan di Muara Sungai Cipunagara mencapai 1,7 km. Air tanah di Desa Muara dan Desa Legon Wetan termasuk air agak payau karena memiliki nilai DHL yang lebih besar dari $1500 \mu \mathrm{S} / \mathrm{cm}$ dan TDS di Legon Wetan > 1000 ppm, sedangkan di Muara TDS nya mendekati 1000 ppm. Perbandingan konsentrasi khlorida-bikarbonat di Desa Muara dan Desa Legon Wetan menunjukkan angka $\mathrm{R}>1$ sehingga tingginya kadar garam pada air tanah diakibatkan oleh intrusi air laut. Hal sebaliknya terjadi di Desa Tegalurung yang penggunaan pantainya didominasi tambak bermangrove memiliki nilai DHL dan TDS air tanah yang masuk dalam klasifikasi air tawar.
\end{abstract}

Kata kunci: abrasi, akresi, garis pantai, intrusi air laut, mangrove.

\begin{abstract}
Changes in land use from forest to other uses are often followed by a decrease in soil functions as a regulator of the water system. This research aimed to study the effect of mangrove cover to a change of a coastline and sea water intrusion in the downstream watershed. The research were focused on determining the type of land use shore via satellite image interpretation and field inspections, analysis of soil physical conditions, observation of seawater intrusion, and analysis of shoreline change due to abrasion or accretion. The results showed in the period of 1989 to 2013, mangrove ponds in Subang decreased from 3402.6 ha to 2384.9 ha, whereas an increase in pond area without mangroves was from 5745 ha to $8741.5 \mathrm{ha}$. Analysis of a shoreline change showed abrasion in Ujung Pamanukan and Ciasem gulf, it reached $1.2 \mathrm{~km}$ inland. Accretion was found in the Blanakan gulf reached $1.3 \mathrm{~km}$ in the period of 1989-2013, while at the Cipunagara estuary reached $1.7 \mathrm{~km}$. The ground water in the Muara and Legon Wetan village included brackish water because it had the DHL that was greater than $1500 \mu \mathrm{S} / \mathrm{cm}$ and TDS in Legon Wetan reached $>1000$ ppm, whereas TDS in Muara village closed to 1,000. Comparison of bicarbonate-chloride concentrations in the Muara and Legon Wetan village showed $R>$ 1 so that high levels of salt in groundwater is caused by seawater intrusion. On the other hand, there was occur in the Tegalurung village that the use of shores was dominated by mangrove ponds had DHL and TDS value groundwater that was classified as plain water.
\end{abstract}

Keywords: abrasion, accretion, mangrove, seawater intrusion, shoreline.

\section{PENDAHULUAN}

Indonesia adalah negara kepulauan dengan garis pantai terpanjang di dunia, sekitar $81.000 \mathrm{~km}$ (Anonim, 2004). Garis pantai tersebut memiliki keanekaragaman ekosistem wilayah pantai, termasuk lahan dan hutan pantai yang sangat potensial sebagai salah satu ekosistem pendukung sistem penyangga kehidupan dan kesejahteraan masyarakat, baik aspek ekonomi, sosial budaya, maupun aspek lingkungan hidup. Pengelolaan wilayah pantai seharusnya dilakukan secara 
bijaksana sebagai bagian integral dari pengelelolaan Daerah Aliran Sungai (DAS). Aktivitas manusia dalam pengelolaan DAS baik di sektor kehutanan, pertanian, pertambangan, industri dan sektor lainnya yang kurang memperhatikan aspek ekologi akan berdampak pada penurunan kualitas lingkungan. Pencemaran air, erosi, sedimentasi, land subsidence, intrusi air laut, perubahan sempadan/garis/bentuk pantai, pendangkalan muara sungai, kerusakan kawasan mangrove merupakan beberapa indikator penurunan kualitas lingkungan yang banyak dijumpai di hilir DAS (Anonim, 2012).

Kawasan hutan wilayah pesisir pada berbagai daerah di Indonesia, terutama di pantai utara Jawa, Sumatera, Sulawesi Selatan, Bali, dan Kalimantan Timur telah mengalami degradasi akibat kerusakan hutan maupun konversi ke pemanfaatan lainnya sebagai pemukiman, tambak, lahan pertanian, lahan perkebunan, atau industri. Menurut Saparinto (2007), saat ini sebagian besar kawasan mangrove berada dalam kondisi rusak, bahkan di beberapa daerah kondisinya sangat memprihatinkan. Tercatat laju degradasi mangrove mencapai 160-200 ribu ha/tahun. Muryani dkk. (2011), mengemukakan bahwa kegiatan pembangunan utama yang memberikan sumbangan terbesar terhadap penurunan mangrove di Indonesia adalah pengambilan kayu untuk keperluan komersil serta peralihan peruntukan untuk tambak dan areal pertanian.

Salah satu akibat dari kerusakan kawasan manrove adalah intrusi air laut. Suryana dkk. (1998) melaporkan bahwa percepatan intrusi air laut di pantai Jakarta meningkat drastis dari $1 \mathrm{~km}$ pada hutan mangrove selebar $0,75 \mathrm{~m}$ menjadi $4,24 \mathrm{~km}$ pada lokasi tanpa hutan mangrove. Secara teoritis diperkirakan percepatan intrusi air laut meningkat 2 - 3 kali pada lokasi tanpa hutan mangrove. Intrusi adalah masuk atau penyusupan air laut ke dalam pori-pori batuan dan mencemari air tanah yang terkandung di dalamnya sehingga menyebabkan air tanah berubah menjadi air payau atau bahkan air asin (Putranto dan Kusuma, 2009).

Ekosistem mangrove mempunyai kemampuan dalam mengendalikan intrusi air laut melalui mekanisme pencegahan pengendapan $\mathrm{CaCO}_{3}$ oleh badan eksudat akar, pengurangan kadar garam oleh bahan organik hasil dekomposisi serasah, peranan fisik susunan akar mangrove yang dapat mengurangi daya jangkauan air pasang ke daratan, dan perbaikan sifat fisik dan kimia tanah melalui dekomposisi serasah (Kusmana, 2010). Kerapatan mangrove berkontribusi terhadap tingkat luasan akresi, distribusi sedimen dan tinggi elevasi permukaan (Kumara dkk., 2010). Namun demikian, penurunan tutupan mangrove dalam skala besar akan mengurangi fungsinya secara fisik sebagai penjaga kestabilan garis pantai, mencegah abrasi, pengendali intrusi, penangkap lumpur dan sedimen, pengendali banjir, serta pemelihara kualitas air (Hilmi, 1998; Soraya dkk., 2012).

Penelitian ini bertujuan untuk mempelajari pengaruh perubahan tutupan managrove terhadap perubahan garis pantai dan intrusi air laut di hilir DAS Ciasem dan DAS Cipunegara, Kabupaten Subang. Hasil penelitian diharapkan dapat menjadi bahan pertimbangan dalam pengembangan wilayah pesisir utamanya di Kabupaten Subang.

\section{METODE PENELITIAN}

\section{Waktu dan Lokasi}

Penelitian dilakukan pada tahun 2014, di hilir DAS Ciasem dan DAS Cipunegara yang secara administratif berada di Kabupaten Subang, Provinsi Jawa Barat. Wilayah pantai Subang ini merupakan kawasan hutan di bawah pengelolaan Perum Perhutani, KPH Purwakarta, BKPH CiasemPamanukan yang terbagi dalam RPH Tegal Tangkil, Muara Ciasem, Poponcol, dan Bobos.

\section{Prosedur Penelitian}

Bahan yang digunakan dalam penelitian ini adalah peta rupa bumi Indonesia (RBI) digital skala 1:25000, Citra Landsat 8, citra satelit resolusi tinggi pada Google Earth Pro, plastik sampel tanah, botol sampel air. Peralatan yang digunakan berupa ring sampel tanah, bor tanah, GPS, meteran, clinometer, kamera, alat tulis, perangkat komputer, dan perlengkapan lapangan.

Penelitian dilakukan untuk mengidentifikasi ada tidaknya intrusi air laut dan perubahan dimensi di wilayah pantai akibat sedimentasi muara sungai, abrasi, atau akresi pada daerah bermangrove dan tidak bermangrove. Kegiatan penelitian meliputi identifikasi penggunaan lahan wilayah pantai melalui penafsiran citra satelit dan validasi di lapangan dan pengamatan intrusi air laut melalui pengambilan sampel air pada sumur-sumur milik masyarakat.

Penggunaan lahan didelineasi dari hasil interpretasi citra satelit terbaru menggunakan Landsat 8. Interpretasi dilakukan secara visual (on screen digitazing) dengan pendekatan kunci interpretasi yaitu bentuk, ukuran, pola, bayangan, rona, tekstur, dan lokasi. Hasil interpretasi dibuat dalam peta penggunaan lahan sementara untuk dicek di lapangan. Selain penutupan lahan terkini, juga dilakukan interpretasi terhadap penggunaan lahan pada 10 dan 20 tahun lalu untuk mempelajari perubahan dimensi fisik lahan di wilayah pantai. Validasi hasil delineasi dilakukan dengan 
pengamatan langsung di lapangan dengan bantuan GPS dan validasi dengan pencocokan penutupan lahan dengan menggunakan citra satelit resolusi tinggi pada Google Earth Pro. Pengecekan lapangan dilakukan untuk memvalidasi peta hasil interpretasi dan menambah informasi yang belum diperoleh saat interpretasi. Pengecekan lapangan dilakukan pada titik contoh yang sebelumnya ditetapkan di peta, selanjutnya saat di lapangan titik-titik pengecekan ditandai menggunakan GPS. Hasil pengecekan lapangan dianalisis untuk menyempurnakan peta penggunaan lahan. Hasil delineasi dan validasi selanjutnya ditabulasi untuk perubahan luasan penggunaan lahan pada tiga periode pengamatan. Untuk mempelajari perubahan garis pantai, dilakukan overlay hasil delineasi penggunaan lahan dengan referensi yang sama pada tiga tahun pengamatan.

\section{Pengumpulan Data}

Pengamatan dilakukan dengan mengambil sampel air pada sumur-sumur milik masyarakat. Titik-titik pengambilan contoh dipetakan dan nilai pada masing-masing titik tersebut diinterpolasi untuk menghasilkan peta tingkat intrusi. Perubahan dimensi wilayah pantai yang diperoleh dari interpretasi citra satelit dan pengamatan di lapangan dianalisis dengan memperhatikan fenomena yang terjadi di lapangan seperti pendangkalan muara atau abrasi yang mengakibatkan genangan banjir.

\section{Analisis Data}

Analisis tingkat intrusi dilakukan dengan menganalisis variabel Daya Hantar Listrik (DHL) dan Total Dissolved Solid (TDS) contoh air sumur. Menurut Octonovrilna dan Pudja (2009), yang dimaksud dengan air asin adalah air yang memiliki kadar garam tinggi yang ditunjukkan dari TDS, di mana air tawar mempunyai TDS kurang dari 1000 $\mathrm{mg} / \mathrm{L}$, sedangkan air tanah payau/asin mempunyai nilai TDS lebih dari $1000 \mathrm{mg} / \mathrm{L}$.

Tingkat keasinan air tanah dibedakan berdasarkan klasifikasi yang disusun oleh Panitia Ad Hoc Intrusi Air Asin Jakarta. Untuk memastikan tingkat keasinan berasal dari intrusi air laut, analisis sampel air juga dilakukan terhadap kandungan $\mathrm{Na}$, $\mathrm{Cl}, \mathrm{CO}_{3}$, dan $\mathrm{HCO}_{3}$. Pada air laut ion $\mathrm{Cl}$ dan $\mathrm{Na}$ lebih dominan, sedangkan pada air tanah ion yang dominan adalah $\mathrm{CO}_{3}$ dan $\mathrm{HCO}_{3}$.

Sesuai dengan Permenkes No. 492/MENKES/PER/IV/2010 telah ditegaskan bahwa untuk sampel air tanah yang memiliki nilai konsentrasi khlorida $(\mathrm{Cl})$ kurang dari $250 \mathrm{mg} / \mathrm{L}$, dinyatakan berkualitas baik dan layak digunakan untuk air minum, selanjutnya untuk sampel air tanah yang memiliki nilai $\mathrm{Cl}$ lebih dari atau sama dengan
$250 \mathrm{mg} / \mathrm{L}$, maka air tanah tersebut berkualitas buruk dan tidak layak untuk digunakan sebagai air minum, air tersebut memiliki tingkat salinitas yang tinggi akibat proses intrusi air laut yang memiliki nilai konsentrasi $\mathrm{Cl}>1000 \mathrm{mg} / \mathrm{L}$, air tanah tersebut dikatakan air tanah telah tercemar (Suhartono dkk., 2013).

Dengan adanya penyusupan air laut, maka komposisi air tanah akan berubah, yaitu ion $\mathrm{Cl}$ akan bertambah sehingga untuk mempelajari adanya penyusupan air laut digunakan Revelle index (El Moujabber, 2006), dengan rumus perbandingan konsentrasi khlorida-bikarbonat (Chlorida bicarbonat ratio) sebagai berikut :

$R=\frac{\mathrm{Cl}}{\mathrm{CO}_{3}+\mathrm{HCO}_{3}}$

di mana $\mathrm{Cl}, \mathrm{CO}_{3}$, dan $\mathrm{HCO}_{3}$ dalam satuan yang sama yaitu $\mathrm{mg} / \mathrm{L}$. Apabila hasilnya $\mathrm{R}>1$ dan harga $\mathrm{DHL}>$ $1500 \mu \mathrm{S} / \mathrm{cm}$, maka keasinan air tanah disebabkan oleh adanya penyusupan air laut, sedangkan bila harga $\mathrm{R}<1$ dan harga DHL $>1500 \mu \mathrm{S} / \mathrm{cm}$, maka keasinan air tanah diakibatkan adanya pelarutan mineral-mineral garam yang terdapat pada batuan akuifer.

\section{HASIL DAN PEMBAHASAN}

\section{Perubahan penggunaan lahan dan garis pantai Subang}

Analisis penggunaan lahan telah dilakukan melalui delineasi citra satelit terkini dengan selang waktu kurang lebih sepuluh tahun. Citra satelit yang tersedia untuk dianalisis adalah Landsat tahun akuisisi 1989, 2001, dan 2013. Hasil delineasi tampak pada Gambar 1.

Gambar 1 menunjukkan bahwa penggunaan lahan pantai di Kabupaten Subang didominasi oleh tambak. Secara umum tambak tersebut memiliki tutupan vegetasi mangrove yang beragam mulai dari kerapatan yang tinggi hingga sama sekali tanpa vegetasi mangrove. Hasil delineasi menunjukkan adanya perubahan luasan penggunaan lahan pada tiga periode pengamatan seperti terlihat pada Tabel 1.

Tabel 1. Perubahan luas penggunaan lahan pantai di Kabupaten Subang.

\begin{tabular}{lccc}
\hline \multicolumn{1}{c}{ Penggunaan } & \multicolumn{3}{c}{ Luas (ha) } \\
\cline { 2 - 4 } lahan & 1989 & 2001 & 2013 \\
\hline $\begin{array}{l}\text { Tambak } \\
\text { bermangrove }\end{array}$ & $3.402,6$ & $5.354,6$ & $2.384,9$ \\
$\begin{array}{l}\text { Tambak non } \\
\text { mangrove }\end{array}$ & $5.745,0$ & $5.626,3$ & $8.741,5$ \\
Sawah & $11.604,2$ & $12.793,9$ & $11.577,0$ \\
\hline
\end{tabular}

Sumber: Hasil analisis. 


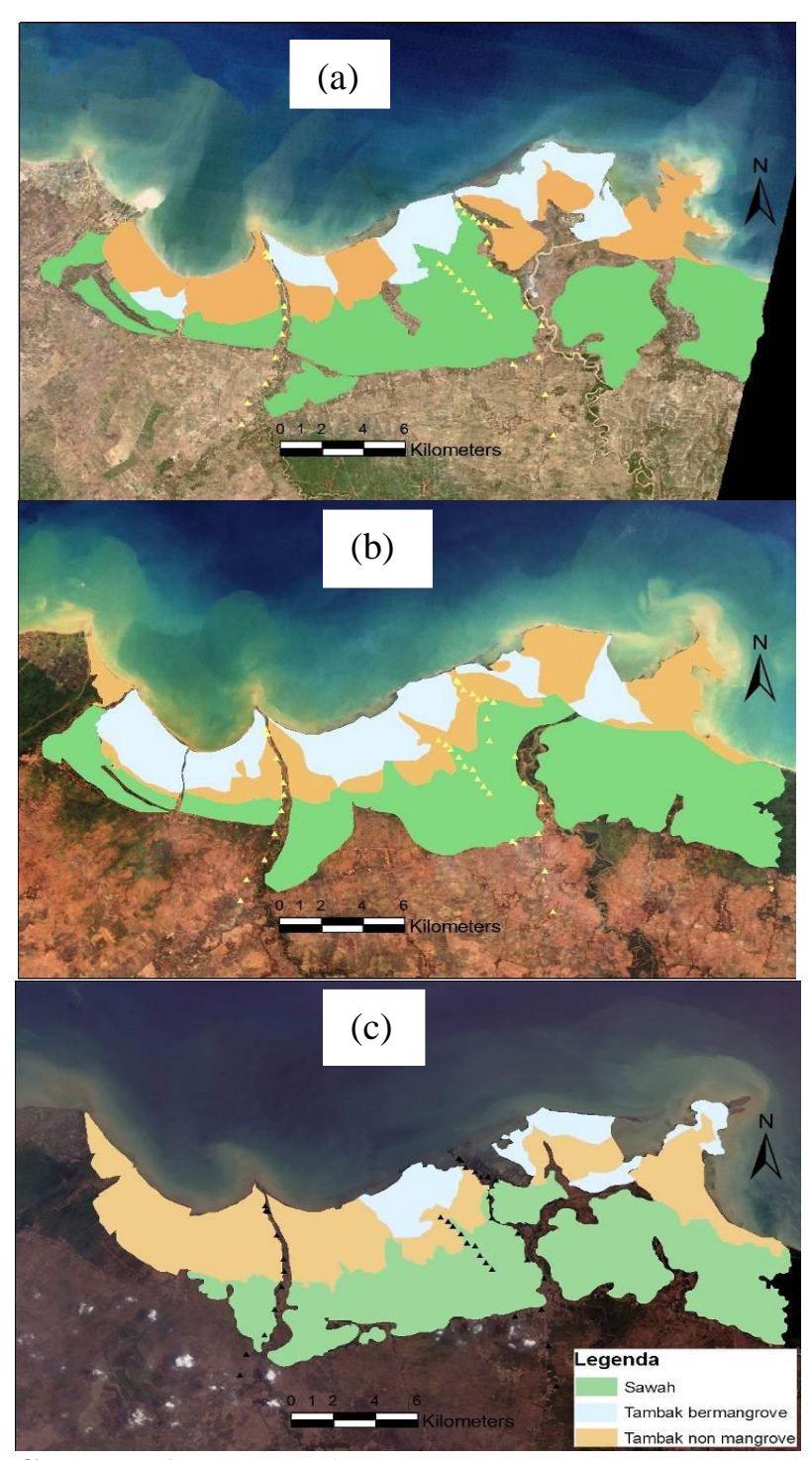

Gambar 1. Hasil delineasi penggunaan lahan pantai di Subang tahun (a) 1989; (b) 2001; dan (c) 2013.
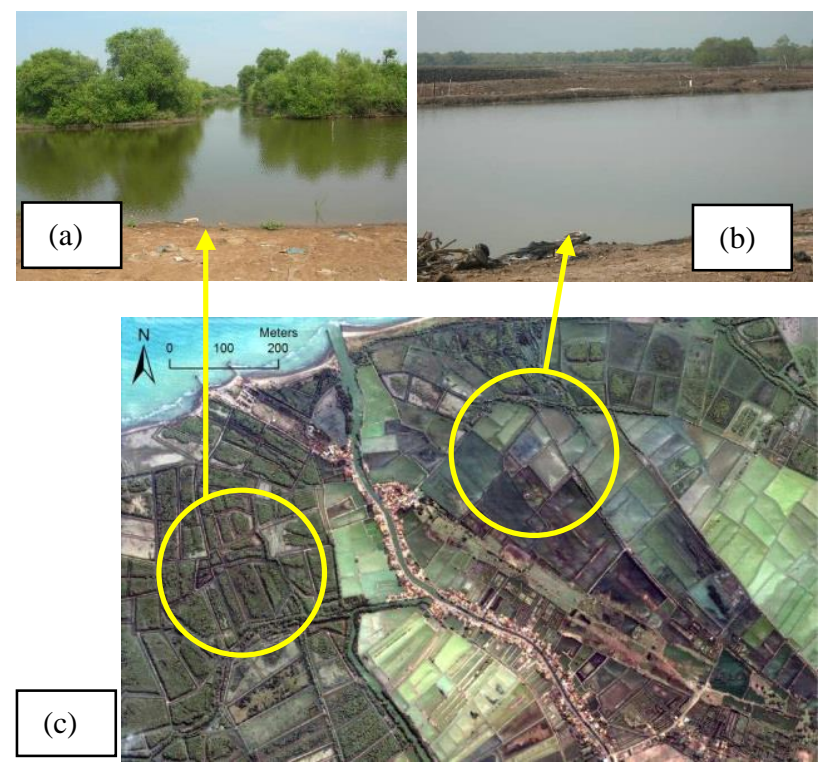

Gambar 2. Tambak dengan (a) tutupan dan (b) tanpa mangrove, serta (c) kenampakan kedua tutupan pada citra satelit.
Penggunaan kawasan hutan mangrove sebagai tambak ikan/udang seharusnya tetap mempertahankan keberadaan tegakan mangrove dengan komposisi mangrove terhadap tambak 60:40 (Saraswati, 2005; Dolorosa dkk., 2014), karena menurut Shinnaka dkk. (2007), kekayaan spesies dan kerapatan ikan secara signifikan menurun pada tempat tidak terdapat mangrove, indeks kemiripan menunjukkan adanya perbedaan komposisi kelompok pada habitat dengan dan tanpa mangrove. Pembuatan tambak ikan 1 ha pada hutan mangrove alam akan menghasilkan ikan/udang sebanyak 287 $\mathrm{kg} / \mathrm{tahun}$, namun kehilangan 1 ha hutan mangrove akan mengakibatkan kerugian $480 \mathrm{~kg}$ ikan dan udang di lepas pantai per tahunnya. Pengurangan hutan mangrove terutama di areal sabuk hijau akan menurunkan produktivitas perikanan tangkap (Anwar dan Gunawan, 2006; Kariada dan Irsadi, 2014). Akan tetapi, kenyataannya lebih banyak petambak yang menghilangkan tegakan mangrovenya seperti tampak pada Gambar 2.

Tambak yang diusahakan dengan tetap memelihara keberadaan mangrove, luasnya cenderung menurun dari tahun 1989 hingga 2013, meskipun pada tahun 2001 terlihat adanya peningkatan cukup besar yang diduga sebagai hasil penananaman mangrove oleh Perum Perhutani pada tahun 1999 seluas 5328,60 ha. Di sisi lain, tambak yang diusahakan tanpa mengombinasikan dengan tegakan mangrove (tumpangsari), luasnya cenderung meningkat hingga 52\% pada tahun 2013. Hasil wawancara dengan masyarakat, diketahui bahwa luasan tambak meningkat secara signifikan sejak era reformasi ditandai dengan pembukaan mangrove secara masif untuk lahan tambak. Kondisi ini sangat memprihatinkan karena mangrove pada daerah pesisir memiliki peranan penting dalam mempertahankan garis pantai. Keberadaan mangrove dapat mencegah proses abrasi pantai serta intrusi air laut. Menurut Filho dkk. (2006), garis pantai mangrove merupakan salah satu indikator terbaik dalam penelitian perubahan pantai secara global.

Analisis tutupan sawah yang berbatasan langsung dengan tambak memiliki luasan yang cenderung tetap. Fakta di lapangan menunjukkan bahwa, di beberapa tempat terutama pada daerahdaerah yang permukaan tanahnya terkena genangan air laut saat pasang naik, masyarakat cenderung mengkonversi sawahnya menjadi tambak. Hasil tumpang susun dari delineasi penggunaan lahan dengan referensi yang sama pada tiga tahun pengamatan terlihat pada Gambar 3.

Berdasarkan hasil tumpang susun penggunaan lahan pada tahun 1989, 2001, dan 2013 dengan background citra Landsat 1989, menunjukkan 


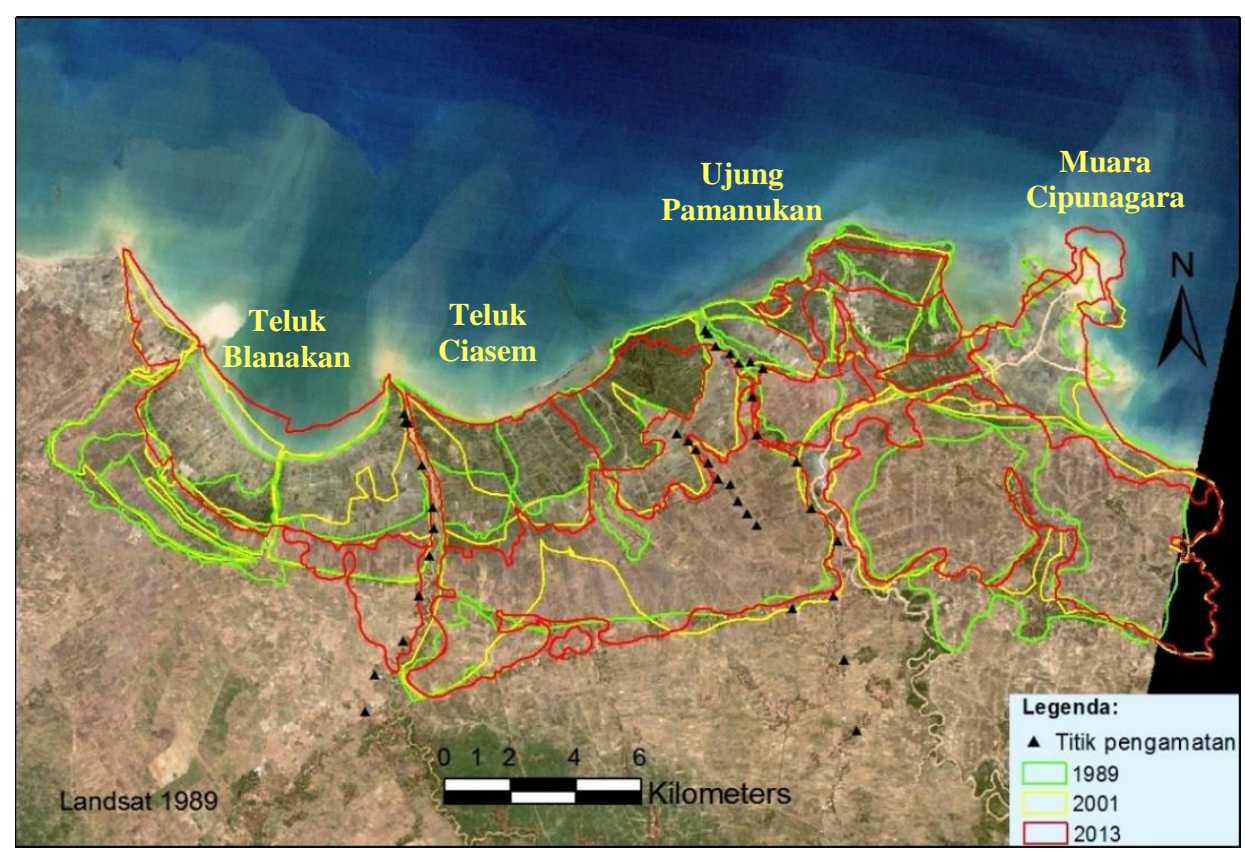

Gambar 3. Perubahan penggunaan lahan dan garis pantai di Kabupaten Subang.

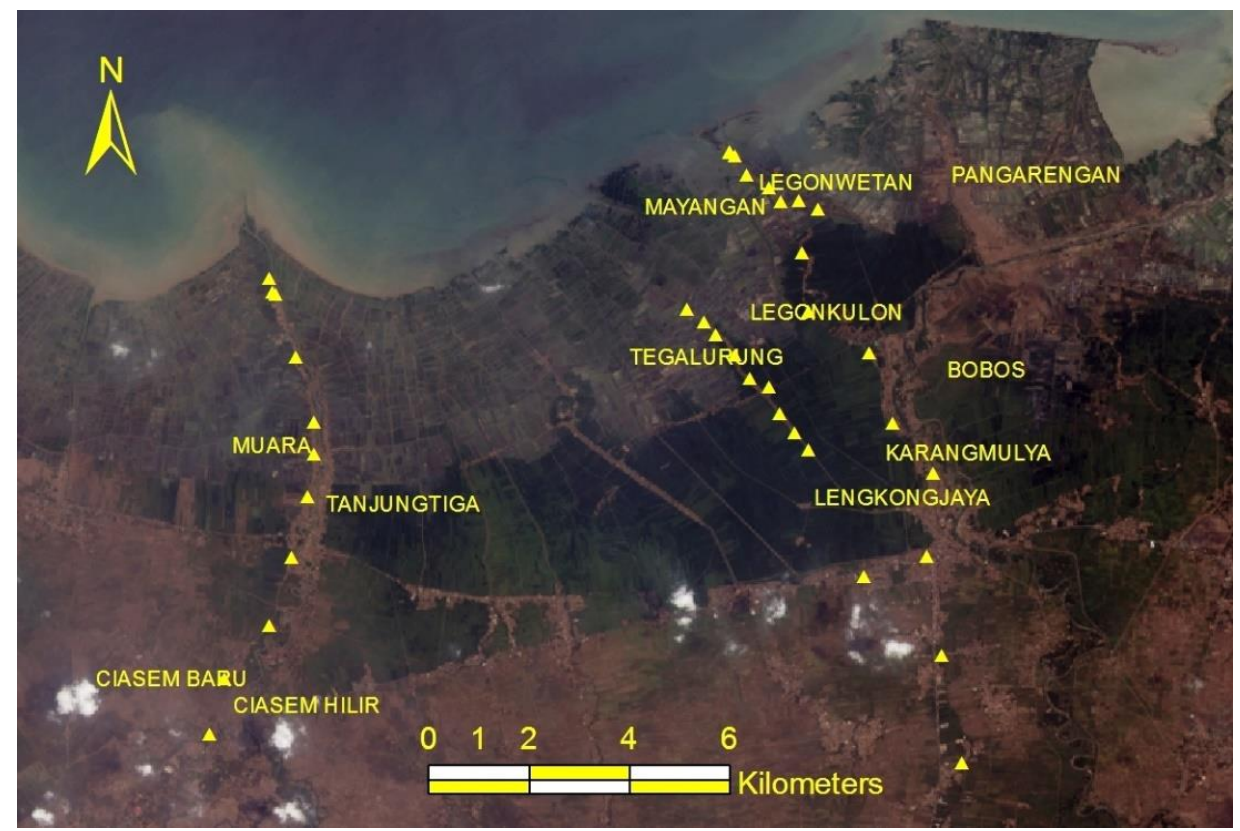

Gambar 4. Titik-titik pengambilan sampel air.

adanya pengurangan luasan daratan (abrasi) dan penambahan luas daratan (akresi). Abrasi terjadi di Ujung Pamanukan dan Teluk Ciasem. Abrasi di Ujung Pamanukan telah merubah garis pantai mundur ke arah daratan hingga 1,2 km. Hal ini mengakibatkan tenggelamnya ratusan hektar tambak dan menggenangi sarana dan prasarana warga seperti pemukiman, jalan, makam, dan fasilitas umum lainnya. Menurut Taofiqurohman dan Ismail (2012), sebagian besar pesisir Kabupaten Subang mengalami abrasi rata-rata sebesar 565,63 m dengan abrasi maksimal sejauh 1206,83 m dalam kurun waktu 14 tahun. Sementara itu, akresi dapat dijumpai di Teluk Blanakan dan Muara Cipunagara, akibat endapan sedimen yang dibawa aliran sungai. Di Teluk Blanakan, yang merupakan tempat bermuaranya aliran Sungai Ciasem, akresi mencapai 1,3 km dalam kurun waktu 24 tahun (tahun 1989 2013), sedangkan di Muara Sungai Cipunagara, dalam kurun yang sama akresi mencapai $1,7 \mathrm{~km}$.

\section{Intrusi air laut}

Secara teoritis air laut memiliki nilai konduktivitas yang tinggi karena mengandung banyak senyawa kimia yang mengakibatkan nilai salinitas dan DHL menjadi tinggi. Oleh karena itu, untuk memprediksi daerah terintrusi air laut dapat dilihat dari pola penyebaran hubungan nilai 
konduktivitas terhadap jarak dari garis pantai. Semakin jauh dari garis pantai secara teoritis nilai konduktivitas semakin kecil (Zain, 2012). Contoh air diambil pada sumur warga di tiga desa utama yaitu Desa Muara, Desa Legon Wetan, dan Desa Tegalurung. Desa Muara dan Desa Legon Wetan merupakan wilayah yang pantainya memiliki penutupan tambak dengan tegakan mangrove yang sangat jarang. Desa Tegalurung merupakan wilayah di Kabupaten Subang yang penutupan tambaknya dikombinasikan dengan tegakan mangrove yang cukup rapat. Posisi titik-titik pengukuran daya hantar listrik dan TDS terlihat pada Gambar 4. Penentuan tingkat keasinan air ditentukan berdasarkan klasifikasi yang disusun oleh Panitia Ad Hoc Intrusi Air Asin Jakarta (Astuti, 2012) sebagaimana tercantum pada Tabel 2 .

Selain pengukuran pada ketiga lokasi tersebut, juga dilakukan pengukuran tingkat keasinan air laut dan air dalam tambak. Rerata hasil pengukuran daya hantar listrik di lokasi disajikan pada Tabel 3. Menurut Zain (2012), DHL menunjukkan kemampuan air untuk menghantarkan aliran listrik. Konduktivitas air tergantung dari konsentrasi ion dan suhu air, oleh karena itu kenaikan TDS akan mempengaruhi kenaikan DHL. Halini dapat dilihat dari hasil pengukuran (Tabel 3).

Hasil pengukuran sampel air menunjukkan air tanah di Desa Muara dan Desa Legon Wetan termasuk air agak payau karena memiliki nilai yang lebih besar dari $1500 \mu \mathrm{S} / \mathrm{cm}$ dan TDS di Legon Wetan > 1000 ppm, sedangkan di Muara TDS nya mendekati 1000 ppm. Sebaliknya, di Desa Tegalurung nilai daya hantar listrik dan TDS sampel airnya masuk dalam klasifikasi air tawar. Analisis statistik telah dilakukan untuk mempelajari pengaruh perbedaan lokasi pengambilan sampel terhadap DHL dan TDL, namun hasilnya tidak

Tabel 2. Klasifikasi keasinan air tanah.

\begin{tabular}{lll}
\hline Sifat air & DHL $(\mu \mathrm{S} / \mathrm{cm})$ & TDS $(\mathrm{ppm})$ \\
\hline Air tawar & $<1500$ & $<1000$ \\
Air agak payau & $1500-5000$ & $1000-3000$ \\
Air payau & $5000-15000$ & $3000-10000$ \\
Air asin & $15000-50000$ & $10000-35000$ \\
Brine (connate) & $>50000$ & $>35000$ \\
\hline
\end{tabular}

Sumber : Astuti (2012). menunjukkan perbedaan yang nyata pada taraf $95 \%$. Hasil perbandingan konsentrasi khlorida-bikarbonat di Desa Muara dan Desa Legon Wetan menunjukkan angka $R>1$ sehingga dapat dinyatakan bahwa kadar garam pada air tanah yang tinggi diakibatkan oleh intrusi air laut.

Berdasarkan analisis penggunaan lahan, Desa Tegalurung merupakan kawasan yang memiliki tutupan mangrove seluas 1075 ha dan relatif rapat dibandingkan kedua lokasi lainnya. Tumbuhan mangrove memiliki korelasi yang tinggi terhadap tingkat intrusi air laut. Keberadaan mangrove memegang peranan penting dalam tata air termasuk mencegah intrusi air laut. Menurut Suryana dkk. (1998) peranan mangrove ini dijabarkan dalam dua cara yaitu perannya dalam menjaga kestabilan muka air tanah dan mengurangi masuknya gelombang laut ke alur sungai. Selain itu Kusmana (2010) juga menerangkan bahwa ekosistem mangrove dapat mengendalikan terjadinya intrusi melalui empat mekanisme yaitu pencegahan secara kimiawi melalui exudate yang dikeluarkan oleh perakaran mangrove, penurunan salinitas air oleh bahan organik yang dihasilkan dari dekomposisi seresah, peran perakaran yang secara fisik menghambat hempasan gelombang laut ke arah daratan, dan memperbaiki kualitas fisika dan kimia tanah melalui dekomposisi seresah.

Hasil penelitian ini juga dikuatkan oleh Sukresno dan Anwar (1999) yang melakukan penelitian di pantai utara Jawa Tengah dan mendapatkan hubungan yang kuat antara kualitas air sumur masyarakat dengan keberadaan mangrove. Di Teluk Banten, konversi 511 ha mangrove menjadi tambak telah menyebabkan intrusi hingga $4 \mathrm{~km}$ dari garis pantai (Ilman dkk., 2011).

\section{KESIMPULAN}

Perubahan tutupan managrove yang terjadi dalam kurun waktu 1989 - 2013 telah menyebabkan perubahan garis pantai dan intrusi air laut di hilir DAS Ciasem dan DAS Cipunegara. Perubahan garis pantai ini merupakan hasil dari proses abrasi di Ujung Pamanukan dan Teluk Ciasem serta proses akresi di Teluk Blanakan dan di Muara Sungai

Tabel 3. Rerata hasil pengukuran DHL dan sifat airnya.

\begin{tabular}{|c|c|c|c|c|c|c|c|c|}
\hline $\begin{array}{c}\text { Lokasi } \\
\text { pengukuran }\end{array}$ & $\begin{array}{c}\text { DHL } \\
(\mu \mathrm{S} / \mathrm{cm})\end{array}$ & $\begin{array}{c}\text { TDS } \\
(\mathrm{ppm})\end{array}$ & $\begin{array}{c}\mathrm{Na} \\
(\mathrm{mg} / \mathrm{L})\end{array}$ & $\begin{array}{c}\mathrm{CI} \\
(\mathrm{mg} / \mathrm{L})\end{array}$ & $\begin{array}{l}\mathrm{HCO}_{3} \\
(\mathrm{mg} / \mathrm{L})\end{array}$ & $\begin{array}{c}\mathrm{CO}_{3} \\
(\mathrm{mg} / \mathrm{L})\end{array}$ & $\begin{array}{c}\mathrm{R} \\
(\mathrm{mg} / \mathrm{L})\end{array}$ & $\begin{array}{l}\text { Kategori } \\
\text { air }\end{array}$ \\
\hline Muara & 1.613 & 813 & 218 & 682 & 257 & 3,1 & 4,9 & agak payau \\
\hline Legon Wetan & 1.895 & 1.113 & 276 & 821 & 167 & 0,0 & 8,4 & agak payau \\
\hline Tegalurung & 963 & 478 & 43 & 151 & 218 & 4,1 & 0,7 & tawar \\
\hline Air laut & 48.980 & 21.700 & 5.136 & 19.425 & 152 & 0,0 & 127,1 & $\operatorname{asin}$ \\
\hline $\begin{array}{l}\text { Air pada saluran } \\
\text { tambak }\end{array}$ & 9.290 & 4.640 & 569 & 2.414 & 96 & 0,0 & 24,9 & payau \\
\hline
\end{tabular}

Sumber: Hasil pengukuran. 
Cipunagara. Intrusi air laut banyak terjadi pada areal yang didominasi tambak tidak bermangrove, ditandai kadar garam air tanah yang tinggi dan perbandingan konsentrasi khlorida-bikarbonat. Untuk meminimalkan bencana abrasi dan intrusi air laut, penanaman mangrove pada pola budidaya tambak perlu terus disosialisasikan mengingat manfaat ekologi dari mangrove begitu penting, di samping bermanfaat dari aspek ekonomi.

\section{UCAPAN TERIMAKASIH}

Ucapan terima kasih disampaikan kepada Badan Litbang dan Inovasi Kementerian Kehutanan Republik Indonesia yang telah membiayai penelitian ini dan Iskandar sebagai teknisi yang telah membantu dalam pelaksanaan penelitian.

\section{DAFTAR PUSTAKA}

Anonim, 2004. Wilayah Kritis Keanekaragaman Hayati di Indonesia: Instrumen Penilaian dan Pemindaian Indikatif/Cepat Bagi Pengambil Kebijakan. Sebuah Studi Kasus Ekosistem Pesisir Laut. Deputi Bidang Sumberdaya Alam dan Lingkungan Hidup Direktorat Pengendalian Sumberdaya Alam dan Lingkungan Hidup. Jakarta.

Anonim, 2012. Daerah Aliran Sungai. www.sipla.pksplipb.or.id. Diakses 3 September 2012.

Anwar, C., dan Gunawan, H., 2006. Peranan Ekologis dan Sosial Ekonomi Hutan Bakau dalam Mendukung Pembangunan Wikayah Pesisir. Prosiding Ekspose Hasil-Hasil Penelitian: Konservasi dan Rehabilitasi Sumberdaya Hutan. Padang, 20 September 2006.

Astuti, T.L.R., 2012. Genesis Air Tanah Asin/Payau di Daerah Parangtritis dan Sekitarnya, Daerah Istimewa Yogyakarta. Buletin Geologi Tata Lingkungan, 22(3):143-154.

Dolorosa, E., Masyhuri, Lestari, dan Jamhari, 2014. Analisis Kelayakan Finansial Usaha Perikanan Tambak Polikultur Bandeng-Udang Windu. Jurnal Social Economic of Agriculture, 3(2):20-36.

El Moujabber, M., Bou-Samra, B., Darwish, T., dan Atallah, T.. 2006. Comparison of Different Indicators for Groundwater Contamination by Seawater Intrusion on the Lebanese Coast. Water Resources Management, 20:161-180.

Filho, P.W.M.S., Martins, E.S.F.M, dan Costa, F.R., 2006. Using Mangroves As A Geological Indicator of Coastal Changes in the Braganca Macrotidal Flat, Brazilian Amazon: A Remote
Sensing Data Approach. Ocean And Coastal Management, 49:462-475.

Hilmi, E., 1998. Penentuan Lebar Optimal Jalur Hijau Mangrove Melalui Pendekatan Sistem (Studi Kasus Di Hutan Mangrove Muara Angke, Jakarta). Tesis Program Pasca Sarjana. Institut Pertanian Bogor, Bogor.

Ilman, M., Wibisono, I.T.C., dan Suryadiputra, I.N.N., 2011. State Of The Art Information on Mangrove Ecosystems in Indonesia. Wetlands International - Indonesia Programme. Bogor.

Kariada, T.M.N., dan Irsadi, A., 2014. Peranan Mangrove sebagai Biofilter Pencemaran Air Wilayah Tambak Bandeng Tapak, Semarang. Jurnal Manusia dan Lingkungan, 21(2):188194.

Kumara, M.P., Jayatissa, L.P., Krauss, K.W., Phillips, D.H., dan Huxam, M., 2010. High Mangrove Density Enhances Surface Accretion, Surface Elevation Change, and Tree Survival in Coastal Areas Susceptible to SeaLevel Rise. Oecologia, 164(2):545-553.

Kusmana, C., 2010. Fungsi Pertahanan dan Keamanan Ekosistem Mangrove. Departemen Silvikultur, Fakultas Kehutanan IPB, Bogor.

Muryani, C., Ahmad, Nugraha, S., dan Utami, T., 2011. Model Pemberdayaan Masyarakat dalam Pengelolaan dan Pelestarian Hutan Mangrove di Pantai Pasuruan Jawa Timur. Jurnal Manusia dan Lingkungan, 18(2):75-84.

Octonovrilna, L., dan Pudja, I.P., 2009. Analisa Perbandingan Anomaly Gravitasi dengan Persebaran Intrusi Air Asin (Studi Kasus Jakarta 2006-2007). Jurnal Meterorologi dan Geofisika, 10(1):39-57.

Putranto, T.P., dan Kusuma, K.I., 2009. Permasalahan Air Tanah pada Daerah Urban. Jurnal Teknik, 30(1):48-57.

Saparinto, 2007. Pendayagunaan Ekosistem Mangrove. PT. Dahara Prize. Semarang.

Saraswati, A.A. 2005. Sylvofishery dalam Pemanfaatan Hutan Mangrove. Alami, 10(3): 44-48.

Shinnaka, T., Sano, M., Ikejima, K., Tongnunui, P., Harinouchi, M., dan Kurokura, H., 2007. Effect of Mangrove Deforestation on Fish Assemblage at Pak Phanang Bay, Southern Thailand. Fisheries Science, 73:862-870.

Soraya, D., Suhara, O., dan Taofiqurohman, A., 2012. Perubahan Garis Pantai Akibat Kerusakan Hutan Mangrove di Kecamatan Blanakan dan Kecamatan Legonkulon, Kabupaten Subang. Jurnal Perikanan dan Kelautan, 3(4):355-364.

Suhartono, E., Purwanto dan Suripin, 2013. Kondisi Intrusi Air Laut terhadap Air Tanah pada 
Akuifer di Kota Semarang. Prosiding Seminar Nasional Pengelolaan Sumberdaya Alam dan Lingkungan. Semarang, 10 September 2013.

Sukresno, dan Anwar, C., 1999. Kajian Intrusi Air Asin pada Kawasan Pantai Berlumpur di Pantai Utara Jawa Tengah. Bulletin Teknologi Pengelolaan DAS 5(1):64-72.

Suryana, Y., Nur, H.S., dan Hilmi, E., 1998. Hubungan Antara Keberadaan Lebar Jalur Mangrove dengan Kondisi Biofisik Ekosistem Mangrove. Fakultas Kehutanan Universitas Winayamukti, Bandung.
Taofiqurohman, dan Ismail, M.FA., 2012. Analisis Spasial Perubahan Garis Pantai di Pesisir Kabupaten Subang Jawa Barat. Jurnal Ilmu dan Teknologi Kelautan Tropis, 4(2):280-289.

Zain, A.H.M.K., 2012. Penurunan Muka Airtanah dan Prediksi Intrusi Air Laut di Kota Tangerang Selatan. Skripsi. Fakultas Teknologi Pertanian, Institut Pertanian Bogor. Bogor. 